\title{
PELATIHAN MANAJEMEN USAHA BUDIDAYA IKAN GURAME (Osphronemus gouramy) DI POKDAKAN MINA GURAME LESTARI DESA UTAMA KECAMATAN CIJEUNGJING KABUPATEN CIAMIS
}

\author{
TRAINING ON GURAME (Osphronemus gouramy) CULTIVATION BUSINESS \\ MANAGEMENT AT POKDAKAN MINA GURAME LESTARI UTAMA VILLAGE, \\ CIJEUNGJING DISTRICT, CIAMIS REGENCY
}

\author{
Saepul Aziz*, Anisa Puspitasari \\ Fakultas Pertanian Universitas Galuh \\ *Email: saepulazizagribisnis@gmail.com \\ (Diterima 01-09-2021; Disetujui 24-09-2021)
}

\begin{abstract}
ABSTRAK
Manajemen usaha budidaya perikanan merupakan suatu kegiatan yang tidak dapat dipisahkan dalam kegiatan budidaya. Salah satu hambatan adalah dalam manajemen budidaya ikan gurami yang belum teratur, sehingga banyak pembudidaya tidak mampu melanjutkan usahanya. Kegiatan pengabdian ini bertujuan untuk memberikan pelatihan dalam manajemen usaha budidaya ikan gurami pada kelompok pembudidaya ikan (Pokdakan) Mina Gurame Lestari di Desa Utama Kecamatan Cijeungjing Kabupaten Ciamis. Metode yang digunakan yaitu metode penyuluhan. kegiatan penyuluhan diikuti oleh 10 orang pembudidaya ikan gurami. Sebagian besar belum memahami manajemen budidaya ikan gurame di kolam plastik/ terpal dengan sistem budidaya instensif, semi intensif serta pemanfaatan fitofarmaka untuk pengobatan ikan. Setelah dilaksanakan penyuluhan, pembudidaya telah mampu memahami manajemen budidaya ikan gurami dengan sistem budidaya intensif, semi intensif serta pemanfaatan fitofarkamaka untuk pengobatan penyakit ikan gurame.
\end{abstract}

Kata kunci: Ikan Gurame, Kolam Plastik/terpal, Fitofarmaka

\section{ABSTRACT}

Management of aquaculture business is an activity that cannot be separated from aquaculture activities. One of the obstacles is the management of gouramy cultivation which has not been organized, so that many cultivators are unable to continue their business. This service activity aims to provide training in the management of the gouramy cultivation business to the Mina Gurami Lestari (Pokdakan) in the Main Village, Cijeungjing District, Ciamis Regency. The method used is the extension method. the counseling activity was attended by 10 gouramy fish farmers. Most of them do not understand the management of carp aquaculture in plastic / tarpaulin ponds with intensive, semi-intensive cultivation systems and the use of phytopharmaca for fish treatment. After the counseling, the cultivators have been able to understand the management of gouramy cultivation with intensive, semi-intensive cultivation systems and the use of phytopharmaceuticals for the treatment of carp disease.

Keywords: Carp, Plastic/tarpaulin ponds, Phytopharmaceuticals

\section{PENDAHULUAN}

Potensi perikanan di Indonesia cukup besar karena hampir di sebagian besar wilayah terdapat sungai, rawa, danau, tambak dan laut. Usaha budidaya gurami dapat dilakukan di tambak, kolam jaring apung, kolam terpal dan keramba. Ikan gurami merupakan ikan air tawar asli Indonesia yang termasuk dalam family labyrinthici. Ikan gurami sudah lama dibudidayakan dan dikonsumsi masyarakat karena rasa dan dagingnya lezat dan memiliki nilai ekonomis yang tinggi (Sari, et al. 2019). 
Pelatihan Manajemen Usaha Budidaya Ikan Gurame (Osphronemus gouramy) di Pokdakan Mina Gurame Lestari Desa Utama Kecamatan Cijeungjing Kabupaten Ciamis

Saepul Aziz, Anisa Puspitasari

Pembudidaya ikan gurame yang tergabung dalam kelompok Mina Gurame Lestari merupakan salah satu mitra P4S Agri Mandiri Lestari yang berada di Desa Utama Kecamatan Cijeungjing Kabupaten Ciamis. Kegiatan yang dilakukan yaitu melakukan budidaya ikan gurami menggunakan media kolam plastik/terpal, kegiatan budidaya gurame di kelompok ini sudah berjalan sejak tahun 2010. Tujuan dibentuknya Kelompok Pembudidaya Ikan (POKDAKAN) Mina Gurame Lestarari sebagai organisasi untuk mempermudah pembudidaya ikan dalam pengeloaan ikan, pakan, kebutuhan air, sarana dan prasarana budidaya ikan.

Manajemen dalam kegiatan usahatani menjadi suatu aktivitas dalam pengorganisasian dan pengoperasian dari beberapa komponen faktor produksi yang lain seperti tanah, tenaga kerja, modal, dan proses budidaya. Keberhasilan suatu usahatani ditentukan oleh bagaimana manajemen yang dijalankan dalam usahatani tersebut (Putri et al. 2020). Beberapa kendala yang dihadapi pembudidaya ikan di Pokdakan Mina Gurame Lestari yaitu proses pertumbuhannya yang lambat. Selain itu, kurangnya pengetahuan dalam hal manajemen usaha yang belum dikuasi oleh pembudidaya ikan gurame sehingga menyebabkan beberapa pembudidaya meninggalkan kegiatan usaha tersebut. Salah satu kelemahan petani di Indonesia ialah terkait dengan masalah pengelolaan usahataninya. Petani biasanya melakukan kegiatan usahanya sebagai bagian dari way of life sehingga proses-proses pengelolaan atau manajemen tidak dilewati sebagaimana mestinya, baik dari mulai tahap perencanaan, pengorganisasian, pelaksanaan, maupun pengontrolan usahanya tersebut. (Febrianti \& Rama, 2019).

Pelaksanaan pengabdian ini bertujuan untuk meningkatkan pengetahuan dan pemahaman petani dalam manajemen usaha budidaya ikan gurami. Sehingga diharapkan, petani akan memahami dan mengerti akan fungsi-fungsi manajemen usaha dan dapat diimplementasikan demi tercapainya peningkatan produktivitas. Proses pencapaian tujuan tersebut diperlukan karena manajemen merupakan sebuah proses untuk mencapai tujuan organisasi. Pencapaian dilakukan dengan cara bekerja bersama-sama dengan orang-orang dan sumberdaya yang dimiliki oleh organisasi (Salmon, 2017).

\section{BAHAN DAN METODE}

Kegiatan pengabdian dilaksanakan di Pokdakan Mina Gurame Lestari Desa Utama Kecamatan Cijeungjing Kabupaten Ciamis pada hari Jum'at 6 Agustus 2021. Alat dan bahan yang digunakan pada saat penyuluhan adalah seperangkat Proyektor (infocus) sebagai alat bantu penyampaian materi serta membantu sasaran dalam memahami materi 
yang disampaikan oleh penyuluh, alat tulis digunakan untuk mencatat absensi sasaran penyuluhan, dan kamera sebagai alat untuk dokumentasi kegiatan. Metode dalam pengabdian ini adalah metode penyuluhan dengan pendekatan pelatihan serta diskusi dengan peserta pelatihan. Metode yang digunakan dalam kegiatan pengabdian masyarakat di Pokdakan Mina Gurame Lestari, yaitu:

1. Observasi

Metode observasi dilaksanakan sebelum pelaksanaan penyuluhan dengan cara koordinasi dengan kelompok pembudidaya ikan Mina Gurame Lestari untuk menyampaikan maksud dan tujuan dari pelaksanaan program pengabdian. Selain itu, observasi sebagai tahapan untuk mendapatkan gambar detail dari permasalahan Pokdakan Mina Gurame Lestari serta sebagai dasar penentuan teknik pelaksanaan program-program yang direncanakan.

2. Diskusi

Proses diskusi dilakukan untuk mendapatkan informasi serta menggali permasalahanpermasalahan yang dihadapi di pokdakan Mina Gurame Lestari dalam melakukan aktivitas selama ini.

3. Penyuluhan

Metode ini bertujuan untuk penyampaian materi tentang manajemen usaha budidaya ikan gurame.

\section{HASIL DAN PEMBAHASAN}

1. Persiapan Pelaksnaan Pengabdian

Persipan program pengabdian di Pokdakan Mina Gurame Lestari dilakukan agar program pengabdian berjalan lancar. Tahapan persiapan dilakukan dengan terlebih dahulu mengunjungi kelompok budidaya ikan Mina Gurame Lestari di Desa Utama Kecamatan Cijeungjing Kabupaten Ciamis dan diskusi dengan pihak terkait. Adanya diskusi awal ini diharapkan semua pihak terkait akan mendukung sepenuhnya program ini baik secara kelembagaan, materil maupun moril.

\section{Tahapan Pelaksanaan}

Manajemen yang diartikan sebagai suatu seni mengelola sumberdaya organisasi untuk mencapai tujuan organisasi untuk menjalankan fungsi dengan baik. (Coulter, 2016; Astuty, 2020). Keberhasilan suatu usahatani ditentukan oleh bagaimana manajemen yang dijalankan dalam usaha tersebut. Pentingnya manajemen dalam usahatani sangat dapat memberikan dampak bagi kelangsungan usahatani, sehingga usahatani yang dijalankan 
Pelatihan Manajemen Usaha Budidaya Ikan Gurame (Osphronemus gouramy) di Pokdakan Mina Gurame Lestari Desa Utama Kecamatan Cijeungjing Kabupaten Ciamis

Saepul Aziz, Anisa Puspitasari

mendapatkan keuntungan yang maksimal secara terus-menerus dengan pemakaian sumberdaya yang ada, meskipun dengan dana atau modal yang terbatas tetapi efektif dan efesien (Butar, 2015; Ratnasari ,2017; Ketty et al, 2020).

Adapun tahapan pelaksanaan program pengabdian ini dilakukan dengan penyampaian materi penyuluhan. materi yang disampaikan berupa materi tentang manajemen dalam budidaya ikan gurami. Penyegaran manajemen organisasi, khususnya pemgelolaan kelompok pembudidaya ikan Mina Gurame lestari.. Materi yang disampaikan diantaranya adalam manajemen pakan dan cara penanganan hama penyakit secara ramah lingkungan.

Manajemen pengelolaan pakan ikan gurame disesuaikan dengan teknik budidaya yang dilakukan. Terdapat dua sistem budidaya, yaitu system budidaya intensif dan semi intensif. Teknik budidaya secara intensif sepenuhnya menggunakan pakan pabrikan tanpa memberikan pakan tambahan dari alam (pakan hijauan) karena padat tebar ikan yang ditebar lebih banyak. Berbeda dengan sistem budidaya semi intensif, perbedaannya pada penambahan pakan hujauan sbagai pakan tambahan yang diberika secara adlibitum (secukupnya).

Penangan penyakit ikan gurami dapat ditangani dengan aplikasi tanaman obat-obatan (fitofarmaka) sebagai bahan alami antimikroba yang ramah lingkungan. Efektifitas beberapa jenis fitofarmaka sebagai anti bakteri Aeromonas hydrophila secara in vitro maupun pada beberapa jenis ikan telah dicoba seperti bawang putih dan meniran (Wahjuningrum et al., 2013), ekstrak daun mengkudu (Hambali et al., 2019).

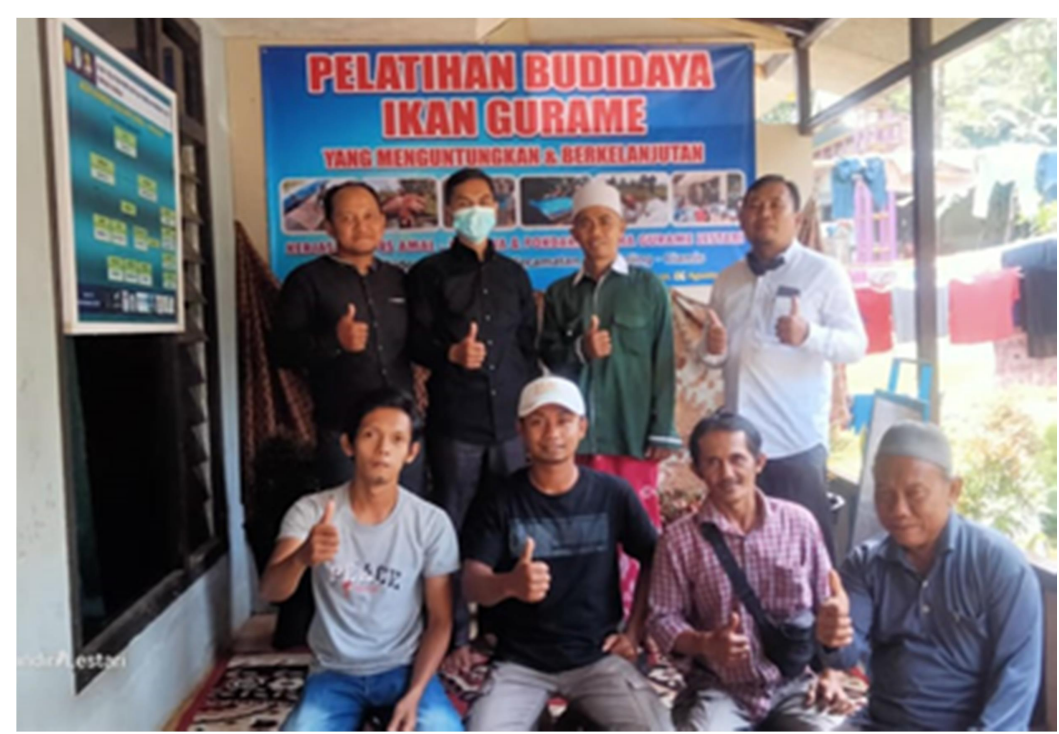

Gambar 1. Peserta Pelatihan Budidaya Ikan Gurame 
Setelah diadakan penyuluhan pembudidaya ikan memberikan respon yang baik dan menambah pengetahuan tentang cara pengelolaan pakan yang baik dan tepat serta penganan penyakit ikan gurami.dan diharapkan kemampuan petani dalam usaha budidaya ikan gurami dapat mencapai produktivitas yang sesuai dengan harapan, sehingga dapat meningkatkan perekonomian para petani ikan gurami pada khususnya. Beberapa penelitian menyebutkan bahwa terdapat korelasi positif antara kemampuan manajemen dengan kinerja/keragaan usahanya. Hal ini menunjukkan apabila kemampuan manajemen semakin meningkat maka kinerja usaha tentu akan meningkat secara optimal, sehingga keberhasilan usaha semakin tercapai (Astuti \& Murwatingsih, 2016).

\section{KESIMPULAN DAN SARAN}

Pengabdian pelatihan manajemen usaha bagi pembudidaya ikan di Pokdakan Mina Gurame Lestari yang telah dilaksanakan, maka dapat diambil kesimpulan yaitu pembudidaya ikan gurami belum mengetahui dan memahami tentang manajemen pemberian pakan pada ikan gurami untuk system pemeliharaan intensif dan semi intensif serta pemanfaatan fitofarmaka sebagai obat untuk mencegah penyakit ikan yang ramah lingkungan. Setelah mengikuti kegiatan penyuluhan pembudidaya ikan dapat mengetahui tentang perlakuan/ manajemen pakan ikan sesuai dengan system pemeliharaan ikan, dan mengetahui tenatang pemanfaatan fitofarmaka untuk pengobatan ikan yang ramah lingkungan.

\section{UCAPAN TERIMA KASIH}

Terimakasih yang sebesar-besarnya kami ucapkan kepada Kelompok Pembudidaya Ikan (Pokdakan) Mina Gurame Lestari dan P4S Agri Mandiri Lesatari yang telah memfasilitasi kegiatan pegabdian ini. Semoga dapat memberikan manfaat.

\section{DAFTAR PUSTAKA}

Astuti, W., \& Murwatingsih. (2016). Pengaruh Kemampuan Mana- jemen dan Karakteristik Usaha terhadap Kinerja Usaha UKM Olahan Produk Salak di Kabupaten Banjarnegara. Manage- ment Analysis Journal, 5(2).

Astuty dan Kurni. 2020. Perbaikan Manajemen Internal KWT Amana Bausasran Manuju Kelompok Tani yang Berkemajuan. Prosiding Semnas PPM. UMY

Hambali, Dewantoro, E., Prasetio, E. 2019. Efektivitas ekstrak daun mengkudu (Morinda citrifolia) sebagai pengobatan ikan jelawat (Leptobarbus hoevenii) yang diinfeksi dengan bakteri Aeromonas hydrophila. Jurnal Borneo Akuatika, 1(2):58-69. 
Putri M. G Ketty, I Nyoman Sirma, dan L. B. (2020). Manajemen Usahatani Terung Ungu di Kelurahan Tuatuka Kecamatan Kupang Timur Kabupaten Kupang. Jurnal EXCELLENTIA, 9(1), 50-57.

Salmon, Kivry E. (2017). Penerapan Fungsi Manajemen Pada Ke- lompok Tani Asi Endo di Desa Tewasen Kecamatan Amurang Barat Kabupaten Minahasa Se- latan. AgriSosio Ekonomi Unsrat, ISSN 1907-4298, Volume 13 No 3A, Nopember 2017.

Salmon, Kivry E. (2017). Penerapan Fungsi Manajemen Pada Kelompok Tani Asi Endo di Desa Tewasen Kecamatan Amurang Barat Kabupaten Minahasa Selatan. Agri-Sosio Ekonomi Unsrat, ISSN 1907-4298, Volume 13 No 3A, Nopember 2017.

Sari, D. O., Kuspramudyaningrum, N. M., \& Vauzati, T. H. (2019). Teknik Pembenihan Ikan Gurame (Osphronemus gouramy) di Unit Kegiatan Budidaya Air Tawar. Prosiding SNMIPA Kolaborasi 2019, 171-178. 